論 文

\title{
芳香族スルフォン酸を触媒とするプロピレンによる プソイドキュメンのイソプロピル化*
}

\author{
堀 江 俊 男**, 勝 山 吉 久**
}

Isopropylation of Pseudocumene with Propylene by using Aromatic Sulfonic Acid as Catalyst*

by Toshio Horie** and Yoshihisa Katsuyama**

\begin{abstract}
Summary : Pseudocumene was isopropylated by using an isopropyl aromatic sulfonate as alkylation agent. This reaction proceeded rapidly at the temperature of $120 \sim 130^{\circ} \mathrm{C}$. The crude product contained $3-, 5-$, and $6-$ isopropyl pseudocumene in the ratio of about $4: 68: 28$. It was found that the same reaction also proceeded with pseudocumene and propylene when aromatic sulfonic acid was added as catalyst. Mono isopropyl pseudocumene could be obtained, as the main product of this catalysed reaction, by controlling reaction conditions, and the ratio of three isomers in it was not influenced by the reaction time. These results show that the above isopropylation is different in reaction mechanism from the isopropylation catalysed by Lewis acid or sulfuric acid. 5-isopropyl pseudocumene was effectively separated by washing the reaction mixture with sulfuric acid. After purification of the isopropylated product, 5-isopropyl pseudocumene with $95 \%$ purity was oblained, and its yield was about $65 \mathrm{~mol} \%$ based on pseudocumene fed under the optimum conditions.
\end{abstract}

\section{1 緒言}

芳香族炭化水素の液相アルキル化触媒としては，一般にプロ トン酸, フリーデルクラフト触媒が用いられるが, 転位等によ る副反応が起こり，目的とする成分を選択的に得ることは困難 である ${ }^{1)-1 。 ~}$

W.J. Hickinbottom らは, スルフォン酸エステルをアルキ ル化㓮にした場合について広䈖囲にわたって検討し ${ }^{5), 6)}$ ，ナフ タレンにおいては, B-アルキルナフタレン, ジフェニルにおい ては，兮ラ置換体を主にした生成物を得るなど独特の挙動を示 すことを見いだした。C. D. Nenitzescu'bはこの反応の機楆 について研究し，スルフォン酸エステルは反忘中オレフィンお よびスルフォン酸と平衡状㸃を保って存在しているとした。

$\mathrm{C}_{6} \mathrm{H}_{5} \mathrm{SO}_{2} \mathrm{OC}_{6} \mathrm{H}_{11} \rightleftarrows \mathrm{C}_{6} \mathrm{H}_{5} \mathrm{SO}_{3} \mathrm{H}+\mathrm{C}_{6} \mathrm{H}_{10}$ $\mathrm{C}_{6} \mathrm{H}_{5} \mathrm{SO}_{2} \mathrm{OC}_{6} \mathrm{H}_{11}+\mathrm{C}_{6} \mathrm{H}_{6} \rightarrow \mathrm{C}_{6} \mathrm{H}_{5} \mathrm{SO}_{3} \mathrm{H}+\mathrm{C}_{6} \mathrm{H}_{5} \mathrm{C}_{6} \mathrm{H}_{11}$

この結果はスルフォン酸エステルの代りに，アルキル化郕と してオレフィンとスルフォン酸を使用することが可能であるこ とを示唆している。

本報告においては，この反応に関してプソイドキュメンのイ ソプロピル化における挙動について調べた。また反応生成物よ り酸化原料等として比較的重要な 5-イソプロピルプソイドキ ニメンを得る方法について検討した。

* 昭和 47 年 4 月 11 日受理!

この報文を「無水ビロメリット酸の合成に関する研究（第 1 報)」 とする。

** 古河電気工業株式会社千葉電線䌘造所（市原市八幡海岸通 6)

Chiba Cable Works, The Furukawa Electric Co., Ltd. (6,

Tori, Yawatakaigan, Ichihara, Chiba)

\section{2 実験}

\section{1 実験装置およひ方法}

ベンゼンスルフォン酸または $p$-トルエンスルフォン酸のイ ソプロピルエステルによりプソイドキュメンをイソプロピル化 するには, 反㗊中にプソイドキュメンと上記エステルを仕込 み，オイルバス中にて反応温度にまで加熱し，かくはんしなが ら反応させた。また，スルフォン酸を触媒として用い，プロピ レンにてイソプロピル化するには，スルフォン酸の1水和物と プソイドキュメンを反忘器中に仕込み、リービッヒコンデンサ 一をつけて約 $170^{\circ} \mathrm{C}$ に加熱して数分間蒸留して結晶水を少熊 のプソイドキュメンとともに共沸させて除いた後, 反応温度に 調節し，定回枟数かくはん機によりかくはんしながら反応混合 物中にそう入した吹込管よりプロピレンを吹き込んでスルフォ ン酸のエステル化反応およびプソイドキュメンのアルキル化反 応を行なった。使用したベンゼンスルフォン酸および $p$-トル エンスルフォン酸 1 水和物は市肘特級品をそのまま使用し，プ ソイドキュメンはサンオイル社製の $98.5 \%$ のものを用いた。 反応途中，入口側のガスメーター D および出口側のガスメー ターKを読み取り而者の差から吸収プロピレン量を求めた。 また経洔変化を観察する場合には，一定時間ごとに反応混合物 $1 \mathrm{~m} l$ を採取し, 冷却後ろ過し，ろ液をガスクロマトグラフィ 一により分析した。

一定時閒反忍させた後の生成物は次のように処理した。まず 反応生成混合物に䄪 2 倍量の $10 \%$ 炭酸ソーダ水溶液を用いて 分液ロート中で洗浄し, 分液した後さらに同量の水で洗浄し, 上層を無水硫酸ソーダを加えて一日脱水した後蒸留し, 未反応 プソイドキュメン $\left(91 \sim 93^{\circ} \mathrm{C} / 68 \mathrm{mmHg}\right)$ ，イソプロピルプソイ 


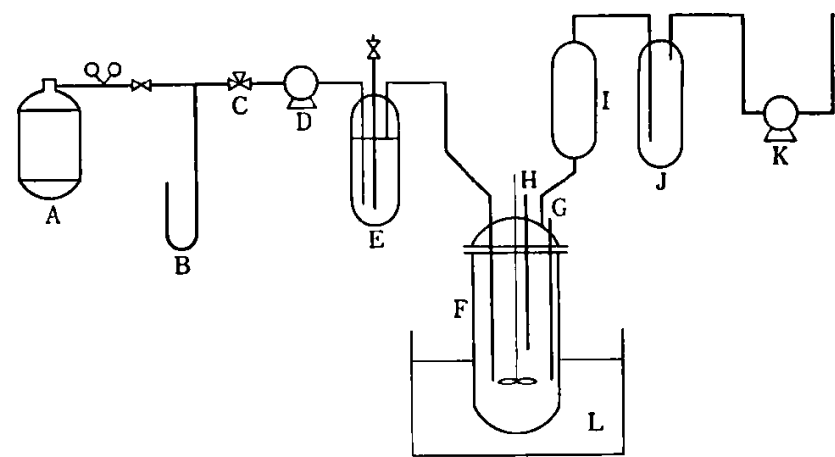

A : Propylene cylinder B : Manometer $\quad$ : : Three way valve $\quad D:$ Gasmeter $\quad E:$ Buffer bottle $\quad F:$ Reactor G: Thermometer H : Outlet for sampling I : Conden. ser $\quad J:$ Water bottle $\quad \mathrm{K}:$ Gasmeter $\quad$ L: Oil bath Fig. 1 Experiment Apparatus

ドキュメン（105 108 $\left.{ }^{\circ} \mathrm{C} / 19 \mathrm{mmHg}\right)$ を採取した後おもにジイ ソプロピルプソイドキュメンを含む残さとに分離した。

このようにして得られたインプロピルプソイドキュメンの異 性体混合物を分液漏斗に入れ，濃硫酸を加えて洗浄し，静置後 上部の油層を分けて, 的同量の $10 \%$ 炭酸ソーダ水溶液, さら に水にて洗浄し, 分離後得られた成分中の 3-, 5-, 6-, イソプ ロピルプソイドキュメンの濃度をガスクロマトグラフィーにて 調ベた。

\section{2 分析方法}

原料および反応生成物の分析はすべて島津製作所 GC-IC 型 ガスクロマトグラフィーを用いて行なった。反応混合物中のプ ソイドキュメン，モノ，ジイソプロピルプソイドキュメンの分 析にはシリコーン DC-550 のカラムを用いて行なった。条件 は次のとおりであった。

キャリアーガス $\mathrm{He}$, 流速 $20 \mathrm{ml} / \mathrm{min}$, カラム (ステンレス 製 $3 \mathrm{~mm} \phi) 3 \mathrm{~m}$, カラム温度 $180^{\circ} \mathrm{C}$ 。

また, イソプロピルプソイドキュメンの各異性体の分析には トリクレジルフォスフェート (T.C.P.) を用いた。条件は次の とおりであった。

キャリアーガス $\mathrm{He}$, 流速 $40 \mathrm{~m} l / \mathrm{min}$, カラム長さ $9 \mathrm{~m}$, 力 ラム温度 $140^{\circ} \mathrm{C}$

各成分の保持時間を Table 1 に示す。

Table 1 Retention Time of Isopropylpseudocumene

\begin{tabular}{|c|c|c|}
\hline $\begin{array}{c}\text { Isopropyl- } \\
\text { Packing } \\
\text { Agent }\end{array}$ & $\begin{array}{l}\text { Mono-Isopropyl } \\
\text { pseudocumene }\end{array}$ & $\begin{array}{l}\text { Di-Isopropyl- } \\
\text { pseudocumene }\end{array}$ \\
\hline Silicon DC 550 & $9 \min$ & $13 \mathrm{~min}$ \\
\hline \multirow{3}{*}{ T. C. P. } & $\begin{array}{l}\text { 3-Isopropyl- min } \\
\text { pseudocumene } 54.5\end{array}$ & \\
\hline & $\begin{array}{l}\text { 4-Isopropyl- } \\
\text { pseudocumene } 44.2\end{array}$ & \\
\hline & $\begin{array}{l}\text { 6-Isopropyl- } \\
\text { pseudocumene } 45.8\end{array}$ & \\
\hline
\end{tabular}

定量分析を行なうには，内部標準物質として $n$-オクタンを 用い，半値幅法により各成分の梌量線を作り行なった。

\section{3 試薬の調製}

2.3.1 ベンゼン（または $p$-トルエン）スルフォン酸インプ ロピルエステルの合成

次の反応にしたがって合成した。

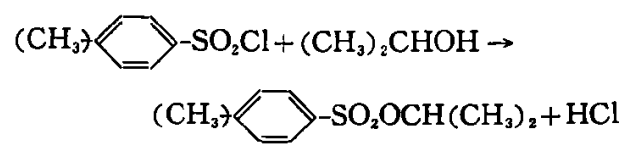

$500 \mathrm{ml}$ の三つロフラスコに $40 \mathrm{~g}$ のイソプロピルアルコー

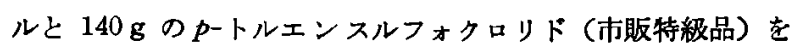
加え, 氷一食塩浴中で冷却し，かくはんしながらピリジン $105 \mathrm{~g}$ を 3 4 時間でゆっくり加えて反応させた後, 塩酸 $200 \mathrm{ml}$ を 加え, ピリジンを溶解し, この水溶液中よりェーテル抽出を行 ない,エーテル液を分離後水洗し, 無水硫酸ソーダで脱水し, 减圧蒸留を行なった。その結果 $150 \sim 152^{\circ} \mathrm{C} / 3 \mathrm{mmHg}$ の留分 $86 \mathrm{~g}$ を得, 元素分析の結果ほほ純粋の $p$-トルエンスルフォン 酸イソプロピルエステルであることを確認した。

ベンゼンスルフォン酸イソプロピルエステルを得る場合もほ

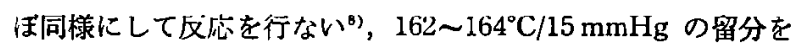
採取した。

\subsection{2 分析用標品の合成}

文献記载の方法に従い，各種の臭素化プソイドキュメンを合 成し，それらについてグリニ坂応を行ない，真素をイソプロ ピル基に置換して各種異性体に相当するインプロピルプソイド キュメンの純品を合成した。

(1）5ーイソプロピルプソイドキニメンの合成”<smiles>Cc1ccc(C)c(C)c1</smiles>

粗生成物を減圧蒸留し, $104 \sim 108^{\circ} \mathrm{C} / 19 \mathrm{mmHg}$ の留分を採 取した。

(2) 6-イソプロピルプソイドキュメンの合成 ${ }^{10)}$<smiles>Cc1ccc(C)c(C)c1</smiles><smiles>Cc1cc(C)c(N)cc1C</smiles><smiles>Cc1cc(C)c(C)c(C(C)C)c1</smiles>

粗生成物を減圧蒸留し， $105 \sim 110^{\circ} \mathrm{C} / 18 \mathrm{mmHg}$ の留分を採 取した。 
(3) 3-イソプロピルプソイドキュメンの合成 ${ }^{\text {B }}$<smiles>Cc1ccc(C)c(COS(=O)(=O)O)c1</smiles><smiles>Cc1cc(C)c([N+](=O)[O-])cc1C</smiles><smiles>Cc1cc([N+](=O)[O-])c(C)c(Br)c1CS(=O)(=O)O[Na]</smiles>

$\mathrm{CH}_{3}$ $\mathrm{CH}_{3}$

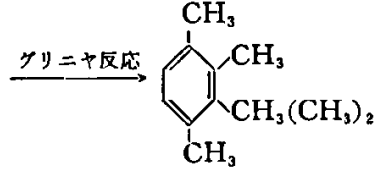

粗生成物を減圧蒸留し $110 \sim 125^{\circ} \mathrm{C} / 20 \mathrm{mmHg}$ の留分を採取 した。

\section{3 結果および考察}

\section{1 スルフォン酸イソプロピルエステル類とプソイドキュ メンとの反応}

2.3.1に述べた方法により合成したベンゼンスルフォン酸お よび pートルェンスルフォン酸のイソプロピルエステルを用い てプソイドキェメンのイソプロピル化を試みた。反応はプソイ ドキュメン $1 \mathrm{~mol}$ に対し両スルフォン酸イソプロピルエステ ル $1.2 \mathrm{~mol}$ を使用して行なった。反応条件および結果を Table 2 に示す。

以上の結果より，この反応は比較的低温において侍間をか けてもほとんど進まず，120 130 $\mathrm{C}$ において急に進行するこ とがわかる。この結果はスルフォン酸エステルが熱分解してア ルキル化反応が進行するとした，前述の W. J. Hickinbottom らの結果とよく一致する。また生成物中の異性体比はどちらの スルフォン酸エステルを用いてもほぼ同じで，5-置換体約 70 \%，6-㯰換体約 30\% よりなり，3-㯰換体はほとんど含まれて いなかった。この事実は一般の親電子的置換反応においてみら れる異性体比とは異なり興味樑い。

Table 2 Products of the Reaction of Pseudocumene and Isopropyl Sufonate

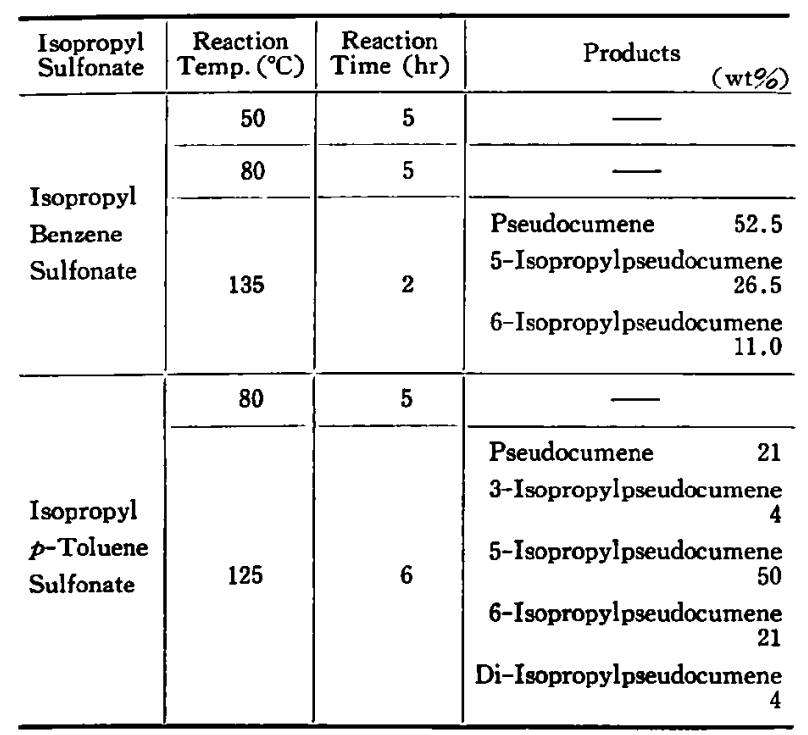

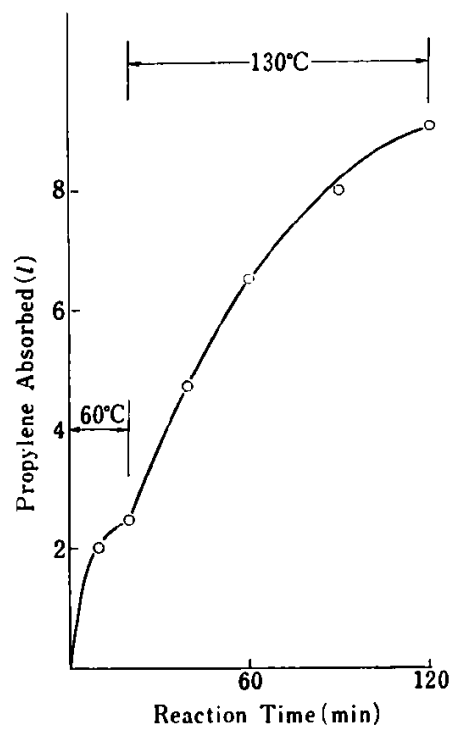

Pseudocumene $\quad 0.883 \mathrm{~mol}$ Benzene sulfonic acid $0.125 \mathrm{~mol}$ Propylene $\quad 300 \mathrm{ml} / \mathrm{min}$ Reaction temp. $\quad 60^{\circ} \mathrm{C}$ or $130^{\circ} \mathrm{C}$

Fig. 2 Effect of Temperature on the Propylene Absorption
次にスルフォン酸類 とプロピレンの反応を 調べるために溶媒もか ねてプソイドキュタン $100 \mathrm{~g} に 0.125 \mathrm{~mol} \sigma$ ベンゼンスルフォン酸 を加光，Fig. 1 に示 した反応装置を用いて 反応させた。プロピレ ンを約 $300 \mathrm{ml} / \mathrm{min}$ で 吹き込み，吸収量を測 定した。その結果を

Fig. 2 に示寸。 この結果より比較的 低温においても反応す るが, 約 $2.5 l$ 吸収し た所で吸収は停止し た。この量はほぼベン ゼンスルフォン酸と等 モルであり，ベンゼン スルフォン酸イソプロ
ピルエステルが生成したものと思われる。

この実験においてさらに温度を上げてプロピレンの吸収量を 測定して行くと，約 $130^{\circ} \mathrm{C}$ 前後から再び吸收が激しく起こりは しめることがわかった。約 $9 l$ のプロピレンが吸収されたとこ ろで反応をやめ，冷却後反応混合物の重量を測定した結果，約 $17 \mathrm{~g}$ 增量していた。結晶をろ過後得られる液体分を分析した結 果, プソイドキニメン $52.5 \mathrm{wt} \%$, モノイソプロピルプソイド キュメン 46.0 wtğ，その他 $1.5 \mathrm{wt}$ ，名含んでいた。この絬 果より約 $130^{\circ} \mathrm{C}$ り始まるプロピレンの吸収は, プソイドキュ メンのイソプロピル化に使用されたものと考えられる。

3.3 スルフォン酸類を触媒として用いたプソイドキュメン のインプロピル化

以上の実験でベンゼンスルフォン酸がプロピレンによるイソ プロピル化の触媒となりらることがわかったのでここの点につ きさらに詳しく調へるるな, 少量のスルフォン酸類を用いて反 応を行ない,プロピレンの吸収速度, 反応生成物の経時変化を 調へててみた。反応は次のようにして行なった。

プソイドキュメン $360 \mathrm{~g}(3 \mathrm{~mol})$, ベンゼンスルフォン酸 1 水和物 $30 \mathrm{~g}(0.17 \mathrm{~mol})$ または $p$-トルエンスルフォン酸 1 水 和物 $32.5 \mathrm{~g}(0.17 \mathrm{~mol})$ を用い, プソイドキュメン $20 \mathrm{~g}$ とと もに結晶水を共沸させた後, 反応温度を $150^{\circ} \mathrm{C}$ に調節してプロ ピレンを吹き込み反応させた。Fig.3 惊雨反応におけるプロピ レンの吸収曲線を示したものでありこれよりベンゼンスルフ オン酸のほらが多少プロピレンの吸収が速いことがかかる。

Fig. 4, 5 注両反応中の生成物の組成変化を示したものであ る。

これら一連の実験より，従来スルフォン酸エステルと芳香族 化合物の反忘に関してのみ報告されていたこの種の反応が，ア ルキル化戍としてオレフィンを用い，これに少量の芳香族スル フォン酸を添加することによっても同様に進行することが明ら 
かになった。すなわち，芳香族スルフォン酸は触媒として働く ものと考えられる。反応機構についてはこれらの実験のみから は明らかではないが，オレフィン，スルフォン酸，およびこれ らのエステルの間に平衡閶係があり，温度が高くなるとスルフ オン酸が增加する方向に平衡が移り，このスルフォン酸が触媒 になってスルフォン酸エステルと芳香族炭化水素が反応するの であろう。

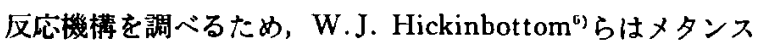
ルフォン酸の $s$-ブチルエステルを用いて実験を行ない，光学: 活性のない生成物が得られることより攻慗試菓はカルボニウム

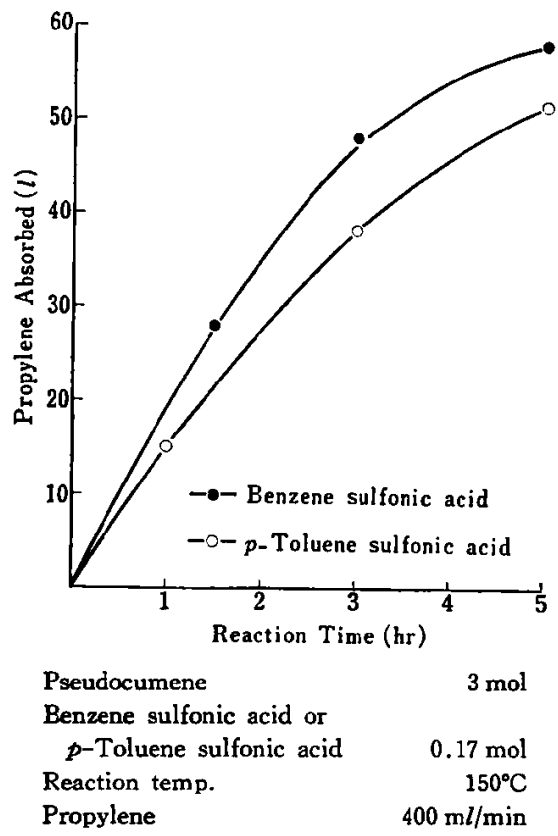

Fig. 3 Propylene Absorption in Isopropylation Catalysed by Sulfonic Acid

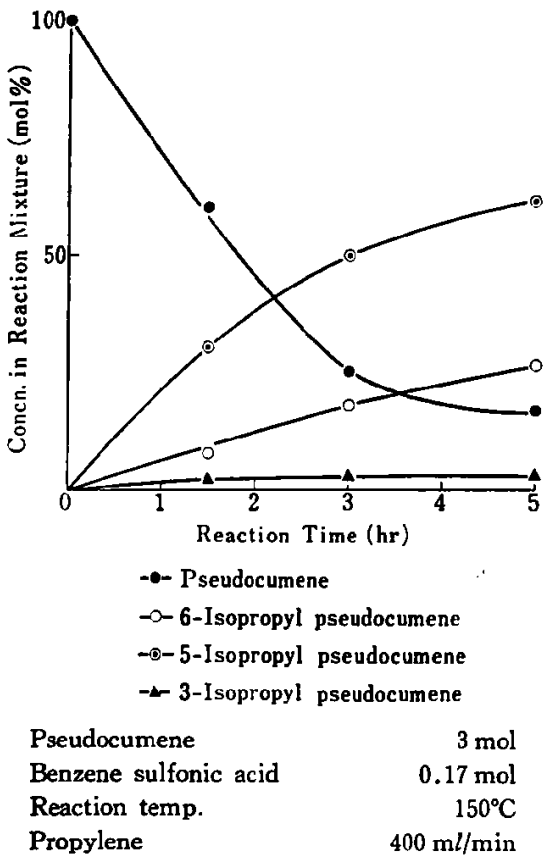

Fig. 4 Relation between Reaction Time and Composition of Reaction Mixture
イオンであるとした。また反応がェステルの分解により，スル フォン酸が生成するとともに起こることより，次のような反応 䅅路を提案している。

$$
\begin{gathered}
\mathrm{ALK} \cdot \mathrm{O} \cdot \mathrm{SO}_{2} \mathrm{R} \stackrel{\mathrm{HOSO}_{2} \mathrm{R}}{\longrightarrow}\left[\mathrm{ALK} \cdot \stackrel{\mathrm{H}}{\mathrm{O}} \cdot \mathrm{SO}_{2} \mathrm{R}\right]+\mathrm{RSO}_{2} \mathrm{O}^{-} \\
{\left[\mathrm{ALK} \cdot \mathrm{O} \cdot \mathrm{SO}_{2} \mathrm{R}\right]^{+} \cdot \mathrm{RSO}_{2} \mathrm{O}^{-} \rightarrow} \\
\mathrm{ALK}^{+}+\mathrm{RSO}_{2} \mathrm{OH}+\mathrm{RSO}_{2} \mathrm{O}^{-} \\
\mathrm{ALK}^{+}+\mathrm{phH}+\mathrm{RSO}_{2} \mathrm{O}^{-} \rightarrow \mathrm{ALKph}+\mathrm{RSO}_{2} \mathrm{OH}
\end{gathered}
$$

しかし，オレフィンの種類によりカルボニウムイオンの生成 のしやすさは違うことやルイス酸触媒を用いるアルキル化にお いても，ラセミ化の程度は酸の強さによりさまざまであること より考えて，スルフォン酸エステルによるアルキル化がすべて 上のような機構によるかどらかは，いちがいにいえないである 5。

\begin{tabular}{|c|c|c|}
\hline 異性休 触 媒 & 塩化てルミニウム & スルフォン酸 \\
\hline 1，2，3，4-䈯 換 体 & $24.5 \%$ & $4 \%$ \\
\hline $1,2,4,5-$ & $44.4 "$ & $70 "$ \\
\hline $1,2,4,6-$ & 31.1 & $26 "$ \\
\hline
\end{tabular}

次に異性体比について考察するため，本実験の異性体比を前 述の G.A. Olah らが行なった塩化アルミニウム触媒による結 果と比校すると次のようになる。

この比較よりスルフォン酸触媒を使用した反応に関し，次の ことがいえる。(1) 1,2,4,5-置換体が多い。(2) 1,2,3,4-㯰換 体が極端に少ない。

これらの相違は塩化アルミニウム触媒よりスルフォン酸触媒 を使用した反応のほらが温度が高いことによる，熱力学的な平 衡からは説明できない。すなわち，温度が高い場合には非対称 の異性体がむしろ多くなる。モノイソプロピルプソイドキュメ ンではないが，たとえばテトラメチルベンゼン類の異性体分布 は次のよらである11。

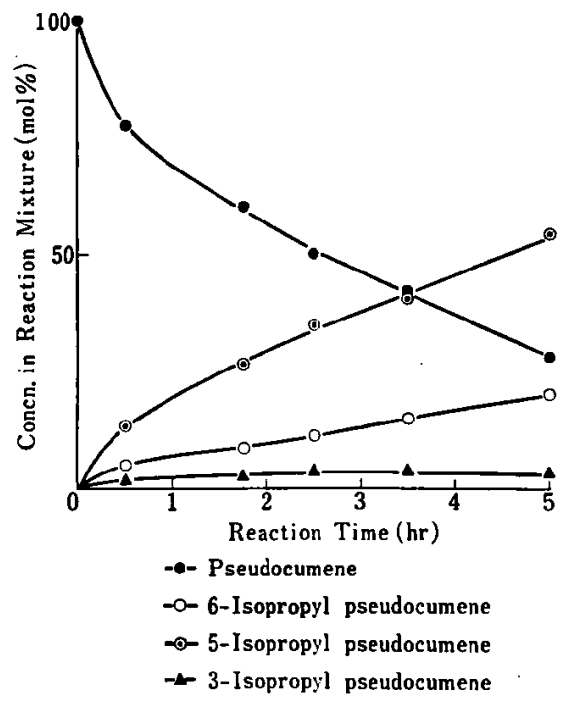

Pseudocumene $3 \mathrm{~mol}$ p-Toluene sulfonic acid $\quad 0.17 \mathrm{~mol}$ Reaction temp. Propylene $150^{\circ} \mathrm{C}$ $400 \mathrm{ml} / \mathrm{min}$

Fig. 5 Relation between Reaction Time and Composition of Reaction Mixture 


\begin{tabular}{l|c|c}
\hline 異性体一温度 & $300^{\circ} \mathrm{K}$ & $700^{\circ} \mathrm{K}$ \\
\hline $1,2,3,4$-置 換 & $8 \%$ & $22 \%$ \\
$1,2,4,5-$ & $45 \%$ & $33 "$ \\
$1,2,3,5-$ & 47. & $45 "$ \\
\hline
\end{tabular}

もし本反応が，オルソ，パラ配向性の親電子的置換反応であ れば, 1,2,4,5一直換体が多量に得られることは十分予測される ことである。しかし，同じオルン，パラ配向性でも，塩化アル ミニウムのような強酸を用いた場合にはメ夕異性体も多く得ら れる。これは $\sigma$ 錯体の段階で脱プロトンを起こす前に㯰換基に 対しオルソ位への転位を起こす等のためであるといわれてい る。たとえば, トルェンのインプロピル化において研究された 例などがある゙。このためにプソイドキュメンのインプロピル 化においても，塩化アルミニウム触媒を用いた場合には， 1,2 , 4,6-置換体がかなり多量に生成寸るものと考えられる。

スルフォン酸ェステルによるアルキル化においては, その異

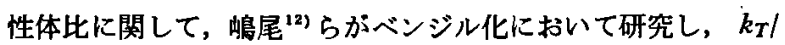
$k_{B}=4.2$ 程度であるのにパラ位の選択性が大きく、この反応は H. C. Brawn の選択則(3)では整理できないことを指摘してい る。そしてこれは，律速段階が $\pi$ 錯体の生成段階にあるためで あり，G.A. Olah らが $\mathrm{NO}_{2}{ }^{+} \mathrm{BF}_{4}$-の親電子試薬を用いた場合 について行なった結果と同種のものであろらとしている。この 性質は，陽性攻試薬が芳香核と相互作用の弱いことを示し， スルフォン酸エステルによるアルキル化における陽性試薬は比 較的弱いものであると予想される。

一般に塩化アルミニウムより弱い酸である臭化アルミニウム を用いると選択性がよくなることなどより考えて，弱い陽性試 薬であると推測されるスルフォン酸を触媒に用いたこの反応の 選択性がよいのであろら。

スルフォン酸を触媒に用いたアルキル化のも5ひとつの特徴 は, 反応中にメチル基およびイソプロピル基の分子間および分 子内の移動がないことである。この反応がイソプロピル化と作 行して起こると, ジュレン等のテトラメチルベンゼン，イソプ ロピルジュレン等のイソプロピル化誘導体が得られるはずであ るが、これらは全く検出されなかった。ルイス酸等を用いた反 态においては, 上記のアルキル基の移動反応が明らかに起こる ことが報告されている゙。これは，たとえば $\mathrm{HF}-\mathrm{BF}_{3}$ 触媒を用

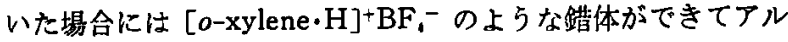
キル基の移動が起こるためと考えられているが゙，スルフォン 酸のみではこのような中間状態が形成されないためにアルキル 基の移動が起こらないのであろうと思われる。

また，本反応において，3-イソプロピルプソイドキュメンが ほとんど得られないことは攻残陽性試薬が非常に大きな分子, たとえば

$$
\begin{gathered}
{\left[\mathrm{R}^{+}-\underset{\uparrow}{\uparrow} \mathrm{OSO}_{2} \mathrm{ph}\right]} \\
\mathrm{H}-\mathrm{OSO}_{2} \mathrm{ph}
\end{gathered}
$$

を想定すると，メチル基にはさまれた位㯰にアルキル化を起こ すにはかなりの立体障害があるためと考えられる。

\section{4 イソプロピルプソイドキュメンの分離}

このよ5にして得られた生成物はほほ 2 種類の異性体よりな るが，これらは沸点が接近しているために蒸留により分離する ことは困難である。しかし，硫酸洗いは，これらを分離するに は十分効果があり，利用度の高い5-イソプロピルプソイドキ ュメンを得るには非常に有利であった。次にそその実験結果を 述べる。

プソイドキュメン $360 \mathrm{~g}$ と p-トルエンスルフォン酸 1 水和 物 $30 \mathrm{~g}$ を用いて前述の方法により10時間反忘させた後 $10 \%$ 炭 酸ソーダ水溶液, 次に水にて洗浄し，油層を分離した後，蒸留 L，66 ${ }^{\circ} \mathrm{C} / 22 \mathrm{mmHg}$ の初留分を $5 \mathrm{~g}$ 留出させた後 $105 \sim 109^{\circ} \mathrm{C}$ $120 \mathrm{mmHg}$ の主留分 $352 \mathrm{~g}$ を得た。残留物は $23 \mathrm{~g}$ であり，そ のらちよりエーテル抽出により $11 \mathrm{~g}$ のジイソプロピルプソイ ドキュメンを得た。主留分を分析した結果 5-イソプロピルプ ソイドキュメン $70.0 \%$ ，6-イソプロピルプソイドキュメン $25.8 \%$ ，3-イソプロピルプソイドキュメン $4.2 \%$ \%得た。

この生成物を $30 \mathrm{~g}$ ずつ10サンプルに分け，これに硫酸を加 えてかくはん後水層より油層を分離し, 炭酸ソーダ水溶液で洗 浄した後分析を行ない，各異性体がどのように油成分中，硫酸 中に分配されるかを調べた。この結果を Table 3 に示す。反 応時間はいずれる 2 分間であった。

以上の結果より，条件を選べば硫酸洗浄により 5-イソプロ ピルプソイドキュメンが高純度で得られることがわかる。能率 よく得るには硫酸の渡度は濃いほうがよく，また常温より加熱 したほうがよいことがわかる。硫酸量は分䧴に大きく影響し，

\begin{tabular}{|c|c|c|c|c|c|c|c|c|c|}
\hline \multirow[b]{2}{*}{$\begin{array}{c}\text { Sample } \\
\text { No. }\end{array}$} & \multicolumn{3}{|c|}{ Washing Conditions } & \multicolumn{3}{|c|}{ Composition of Oil Layer after Washing } & \multicolumn{3}{|c|}{ Composition of $\mathrm{H}_{2} \mathrm{SO}_{4}$ Solu. } \\
\hline & $\begin{array}{c}\mathrm{H}_{2} \mathrm{SO} \\
\text { Conen. } \\
(\%)\end{array}$ & $\frac{\mathrm{H}_{2} \mathrm{SO}_{4}(\mathrm{~m} l)}{\mid \begin{array}{l}\text { Isopropyl- } \\
\text { pseudocumene } \\
(\mathrm{m} l)\end{array}}$ & $\begin{array}{l}\text { Temp. } \\
\left({ }^{\circ} \mathrm{C}\right)\end{array}$ & $\begin{array}{c}\text { 5-Isopropyl- } \\
\text { pseudocumene } \\
(g)\end{array}$ & $\begin{array}{c}\text { 6-Isopropyl- } \\
\text { pseudocumene } \\
\text { (g) }\end{array}$ & $\begin{array}{c}\text { 3-Isopropyl- } \\
\text { pseudocumene } \\
\text { (g) }\end{array}$ & $\begin{array}{l}\text { 5-Isopropyl- } \\
\text { pseudocumene } \\
\text { (g) }\end{array}$ & $\begin{array}{c}\text { 6-Isopropyl- } \\
\text { pseudocumene } \\
\text { (g) }\end{array}$ & $\begin{array}{l}\text { 3-Isopropyl- } \\
\text { pseudocumene } \\
\text { (g) }\end{array}$ \\
\hline S- 1 & 98 & 0.5 & 20 & 19.3 & 2.2 & 0 & 1.7 & 5.6 & 1.2 \\
\hline S- 2 & 83 & 1.5 & 20 & 18.2 & 7.3 & 1.1 & 2.8 & 0.5 & 0.1 \\
\hline$s-3$ & 98 & 1.5 & 20 & 8.3 & $\mathbf{0}$ & 0 & 12.7 & 7.8 & 1.2 \\
\hline$S-4$ & 83 & 0.5 & 20 & 16.4 & 6.6 & 1.1 & 4.6 & 1.2 & 0.1 \\
\hline S- 5 & 98 & 0.5 & 40 & 17.7 & 0 & 0 & 3.3 & 7.8 & 1.2 \\
\hline S- 6 & 83 & 1.5 & 40 & 17.5 & 6.2 & 1.0 & 3.5 & 1.6 & 0.2 \\
\hline S- 7 & 98 & 1.5 & 40 & 11.3 & 0 & $\mathbf{0}$ & 9.7 & 7.8 & 1.2 \\
\hline S- 8 & 83 & 0.5 & 40 & 19.2 & 6.1 & 1.2 & 1.8 & 1.7 & 0 \\
\hline S- 9 & 98 & 0.3 & 40 & 19.5 & 1.9 & 0 & 1.5 & 5.9 & 1.2 \\
\hline S-10 & 98 & 0.2 & 40 & 21.0 & 1.1 & 0 & 0 & 6.7 & 1.2 \\
\hline S-11 & & No Washing & & 21.0 & 7.8 & 1.2 & - & - & - \\
\hline
\end{tabular}

Table 3 Isomer Distribution in Oil Layer and Water Layer after Washing Mono-isopropylpseudocumene with $\mathrm{H}_{2} \mathrm{SO}_{4}$ Solution 
硫酸を適聂使用することにより S-10のようにほぼ定量的に 5イソプロピルプソイドキュメンを残すことができ，しかも約 95 \%の純度で得ることができる。この現象は, 丽異性体のスルフ オン化に対する難易度の相違によるのであるが，3-インプロピ ルプソイドキュメンのスルフォン化されやすさは，5-イソプロ ピルプソイドキュメンと同程度であり，この両者を分雄するこ とはできない。したがって，この分離法により，5-イソプロピ ルプソイドキュメンを得るには, あらかじ3-イソプロピルブ ソイドキュメンを含まないるのを使用することが必要である。

イソプロピルプソイドキュメン各種異性体のスルフォン化の 難易度は，それらの塩基性度によると思われるが，これらの文 献記載值はみあたらない。しかし，テトラメチルベンゼンに関 しては D.A. McCaulay (1) らが， p-キシレンに対する相対的塩 基度を求めている。それによると，1，2，4，5-圆換体 $60 ， 1$ ， 2,3，4-直換体 85，1，2，3，5-置換体 2,800である。

この值より前二者の塩基度はほぼ同等であるのに比べ, 後者 は大きく，スルフォン化が非常にされやすいことがかかる。こ の上5に分嚾効果の大きいスルフォン化分䧸法がテトラメチル ベンゼン異性体分潅に用いられないのは $16 \mathrm{~mol} / l$ 以上の浱度 の硫酸では，1，2，4，5-異性体は容易に 1,2,3，5-異性体に変 化し，かつスルフォン化されるためである”。しかし，5-イン プロピルプソイドキュメンでは硫酸中でのアルキル基の転位は 全く起こらないため,この方法による分離が十分可能になるの であろら。

\section{4 結言 \\ 以上述べた一連の実験結果より次のことがいえる。}

（1） ベンゼンまたは p-トルエンスルフォン酸を触媒とし て, $120 \sim 130^{\circ} \mathrm{C}$ 以上の温度でプロピレンとプソイドキュメン を反応させることにより，イソプロピルプソイドキュメンを得 ることができる。

（2）このよ5にして得られたイソプロピルプソイドキュメ ンの異性体比は，他の触媒を使用して得られる異性体比とは異 なり，3-イソプロピルプソイドキュメン約 $4 \%$ ，5-イソプロピ ルプソイドキュメン約 $70 \%$ ，6-イソプロピルプソイドキュメ ン約 $26 \%$ よりなっている。

この異性体比は反応中ほぼ一定値を保ち，反応中または反応 後の異性化は起こらないと考えられる。

（3）以上の上5な組成の生成物を溜硫酸で洗浄することに より，5-イソプロピルプソイドキュメンのみをほぼ選択的に得 ることができ, 純度 95 名 以上のものをプソイドキュメンより 収率約 $65 \mathrm{~mol} \%$ で得ることができる。

\section{引用文献}

1) Lutz, E.F., U.S. $3,132,189$.

2) McCaulay, D.A., J. Am. Chem. Soc., 74, 6246 (1952)

3) Kilpatrick, M., J. Phys. Chem., 65, (8), 1312 (1961).

4) Olah, G.A., J. Am. Chem. Soc., 86, 1046 (1964).

5) Hickinbottom, J., J. Chem. Soc., 2509 (1959).

6) Hickinbottom, J., ibid., 2520 (1959).

7) Nenitzescu. C.D., Chem. Ber., 90, 585 (1957).

8) Sekera, V.C., J. Am. Chem. Soc., 55, 345 (1933).

9) Smith, L.I., ibid., 58, 1 (1936).

10) Wals, L., Recueil, 87, 65 (1968).

11) Hastings, S.H., J. Phys. Chem., 61, (6), 730 (1957).

12）鸠尾一郎, 日化誌, 88, (12), 1311 (1967).

13) Stock, L.M., J. Am. Chem. Soc., 81, 3323(1959).

14) McCaulay, D.A., ibid., 73, 2013 (1951). 